\title{
Electrodeposition of $\mathrm{CeO}_{2}$ and $\mathrm{Pd}-\mathrm{CeO}_{2}$ on small pore size metallic foams: Selection of deposition parameters
}

\author{
Phuoc Hoang $\mathrm{Ho}^{\mathrm{a}, \mathrm{b}}$, Matteo Ambrosetti ${ }^{\mathrm{c}}$, Gianpiero Groppi ${ }^{\mathrm{c}, *}$, Enrico Tronconi ${ }^{\mathrm{c}}$, \\ Giuseppe Fornasari ${ }^{\mathrm{a}}$, Angelo Vaccari ${ }^{\mathrm{a}}$, Patricia Benito ${ }^{\mathrm{a},}$ \\ a Dipartimento di Chimica Industriale “Toso Montanari”, Università di Bologna, Viale Risorgimento 4, 40136, Bologna, Italy \\ ${ }^{\mathrm{b}}$ Institut für Technische und Makromolekulare Chemie, RWTH Aachen University, Worringerweg 2, 52074, Aachen, Germany \\ ${ }^{\mathrm{c}}$ Laboratory of Catalysis and Catalytic Processes, Dipartimento di Energia, Politecnico di Milano, Via La Masa 34, 20156, Milano, Italy
}

\section{A R T I C L E I N F O}

\section{Keywords:}

$\mathrm{CeO}_{2}$

Palladium

Electrodeposition

Metallic open cell foam

Structured catalyst

CO oxidation

\begin{abstract}
A B S T R A C T
The electrodeposition, in particular the electro-base generation method, is an alternative to conventiona washcoating to coat open-cell metallic foams, especially small pore size ones. In this work, the method was applied for the in-situ synthesis of cerium-based coatings, $\mathrm{CeO}_{2}$ and $\mathrm{Pd}-\mathrm{CeO}_{2}$, on 100 pores per inch (ppi) FeCrAl foams. The range of parameters suitable for the electrodeposition of $\mathrm{CeO}_{2}$ films of different thickness and morphology was firstly investigated, i.e. $\mathrm{Ce}\left(\mathrm{NO}_{3}\right)_{3}$ concentration, potential applied, and deposition time. Then the most challenging one step $\mathrm{Pd}-\mathrm{CeO}_{2}$ electrodeposition was studied; the Pd content and distribution were optimized considering also the electrochemistry and chemistry of $\mathrm{Pd}^{2+}$ species, i.e. by selection of a suitable $\mathrm{Pd}^{2+}$ complex precursor $\left(\mathrm{Pd}\left(\mathrm{NH}_{3}\right)_{4}\left(\mathrm{NO}_{3}\right)_{2}\right.$ or $\mathrm{PdCl}_{2}$ in $\left.\mathrm{HCl}\right)$. Coated foams were calcined at $550{ }^{\circ} \mathrm{C}$ to obtain the structured catalysts. The $\mathrm{CO}$ oxidation was used as a model reaction to test the activity of $\mathrm{Pd}_{-} \mathrm{CeO}_{2}$ catalysts.

The electrodeposition of cubic fluorite $\mathrm{CeO}_{2}$ coatings on the surface of the foam ranging from few to $18 \mu \mathrm{m}$ and made by compact and/or platelet particles was easily achieved and with a high reproducibility. The $\mathrm{Pd}^{-\mathrm{CeO}_{2}}$ samples prepared from the ammine-containing electrolyte, though generated a well-adhered coating, resulted in a lower Pd content than the nominal value of the electrolyte. A high electrolyte concentration containing $\mathrm{PdCl}_{2}$ combined with a short time allowed to deposit a rather thick Pd-containing $\mathrm{CeO}_{2}$ coating avoiding the massive $\mathrm{Pd}^{\circ}$ deposition. $\mathrm{CO}$ oxidation tests, especially at high flow rates, confirmed the key role of the coating and Pd distribution on the activity of the structured catalysts. A comparison of the conversion in mass transfer regime and estimates with literature correlations was presented, showing that, despite the very complex geometry of the support, a remarkably high quantity of the available surface is effectively exploited, paving the way for compact catalytic converters.
\end{abstract}

\section{Introduction}

$\mathrm{CeO}_{2}$-based coatings on 3D supports result in promising structured catalysts for environmental catalytic processes, three way catalysts (TWCs) [1,2] and $\mathrm{CH}_{4}$ combustion [3], preferential $\mathrm{CO}$ oxidation [4], and syngasrelated processes, i.e. reforming [5] and water gas shift [6,7], among others. In these structured catalysts, the advantages of dispersing a metal into the redox $\mathrm{CeO}_{2}$ support with oxygen storage capacity $[1,8]$ are combined with those of the structured support [9]. The coating procedure needs to be optimized to achieve a good coverage and adhesion of the catalysts to the 3D support, especially to small pore size metallic ones, and to avoid any modification in the $\mathrm{CeO}_{2}$ properties (its surface area and defects are of paramount importance to tailor the catalytic performances). The dip-coating in acid-free conditions fulfils some of these requirements [5]. The synthesis of $\mathrm{CeO}_{2}$ or $\mathrm{CeO}_{2}$-based catalysts on the 3D support by an electrochemical route can be considered as an alternative to the conventional procedure to coat small pore size foams avoiding pore blockage.

The electro-base generation method is a cost effective and green method with low material waste to quickly precipitate $\mathrm{CeO}_{2}$ (or cerium hydroxides) directly onto simple shaped metal substrates such as $\mathrm{Cu}$ [10], stainless steel [11,12], Ni [13], Ni alloy [14], and Ti alloy [15], which has been widely used for anticorrosion purposes. To control the nucleation, growth, and crack formation of pristine $\mathrm{CeO}_{2}$, several cerium precursors $\left(\mathrm{CeCl}_{3}\right.$ and $\mathrm{Ce}$ $\left.\left(\mathrm{NO}_{3}\right)_{3}\right)$ [13] in concentrations ranging from a few $\mathrm{mM}[16,17]$ to 0.10.25 M [14,18-20], solvents (mainly water but also alcohols) [13,16], additives (PVP) [16], and deposition parameters (e.g. temperature and applied current) $[11,19]$ were investigated. In a $\mathrm{CeCl}_{3}$ solution saturated with $\mathrm{O}_{2}$, the reduction of $\mathrm{O}_{2}$ is reported to both increase the $\mathrm{pH}$ and oxidize $\mathrm{Ce}^{3+}$ to

\footnotetext{
* Corresponding authors.

E-mail addresses: gianpiero.groppi@polimi.it (G. Groppi), patricia.benito3@unibo.it (P. Benito).
} 
$\mathrm{Ce}^{4+}$; this latter process is enhanced by the generation of the $\mathrm{H}_{2} \mathrm{O}_{2}$ intermediate $\mathrm{Ce}(\mathrm{OH})_{2}{ }^{2+}[10]$. On the other hand, for $\mathrm{Ce}\left(\mathrm{NO}_{3}\right)_{3}$, although the $\mathrm{NO}_{3}{ }^{-}$reduction to $\mathrm{NO}_{2}{ }^{-}$or $\mathrm{NH}_{4}{ }^{+}$could be responsible for the $\mathrm{pH}$ increase, its role has been sometimes discarded [14].

Coatings for catalytic applications can be obtained from concentrated $\mathrm{Ce}\left(\mathrm{NO}_{3}\right)_{3}$ aqueous electrolytes, i.e. 0.1 M [21]. A high current density (up to $50 \mathrm{~A} \mathrm{~m}^{-2}$ ), applied to supports dipped in concentrated electrolytes, decrease the particle and crystallite size since nucleation is favoured against growth [15,19], and increase the amount of oxygen vacancies [22]. However, at very high current intensities the precipitation mechanism is predominant and there are not changes in the sizes [18]. Particle shapes, spherical and needle-like, are also reported to depend on the $\mathrm{Ce}\left(\mathrm{NO}_{3}\right)_{3}$ concentration $[16,18]$, the former is related to $\mathrm{CeO}_{2}$ and the latter to $\mathrm{Ce}(\mathrm{OH})_{3}$. However, other parameters such as the composition of the substrate and the electrochemical conditions seem to determine the electrodeposited crystalline phases [22]. The effect of the preparation parameters has been also observed in the coatings after calcination [15].

Electrodeposition enables co-depositing cerium with other elements such as cobalt, nickel, and samarium to obtain $\mathrm{Ce}_{1-\mathrm{x}} \mathrm{Co}_{\mathrm{x}} \mathrm{O}_{2-\delta}$ nanorods on $\mathrm{Cu}$ [23], nickel-cerium hydroxides on stainless steel mesh [24], and $\mathrm{Sm}^{3+}$ doped $\mathrm{CeO}_{2}$ on $\mathrm{Pt}[25,26]$. When dealing with highly reducible species, such $\mathrm{Pt}$, a film of $\mathrm{Pt}^{\circ}$ particles well dispersed and embedded in a porous $\mathrm{CeO}_{2}$ substrate is electrodeposited on a glassy carbon electrode [27]. In the preparation of $\mathrm{Pt}-\mathrm{CeO}_{2}$ coatings on $\mathrm{FeCrAl}$ foams for methanol combustion, the two-step pulsed electrodeposition of Pt nanoparticles from a $\mathrm{H}_{2} \mathrm{PtCl}_{6}$ solution followed by cathodic electrodeposition of $\mathrm{CeO}_{2}$ thin films from a nitrate bath is more successful than the simultaneous cathodic electrodeposition of $\mathrm{Pt}$ and $\mathrm{CeO}_{2}$ [21].

In our previous work, we report the feasibility of the electrodeposition to prepare $\mathrm{CeO}_{2}$ and $\mathrm{Pd}-\mathrm{CeO}_{2}$ coatings on high pore density open-cell FeCrAl foams for environmental catalytic applications [28]. In a one-step $\mathrm{Pd}-\mathrm{CeO}_{2}$ electrodeposition, $\mathrm{Pd}^{2+}$ is incorporated into the $\mathrm{CeO}_{2}$ structure forming the solid solution and precipitated as $\mathrm{Pd}^{\circ}$; the properties of the coating are largely preserved after calcination at $550^{\circ} \mathrm{C}$. The resulting structured catalysts show highly active and stable performances in the mass transfer limited CO oxidation.

Here we report the preliminary work performed to prepare these catalysts with a twofold aim of: i) optimizing the range of preparative conditions to deposit $\mathrm{CeO}_{2}$ coatings on open-cell foams using $\mathrm{Ce}\left(\mathrm{NO}_{3}\right)_{3}$ as precursor; ii) controlling the co-deposition of $\mathrm{Pd}^{2+}$ and $\mathrm{CeO}_{2}$, paying special attention to the chemistry and electrochemistry of $\mathrm{Pd}^{2+}$.

$\mathrm{Pd}^{2+}$ is highly reducible and its electrodeposition, after electroreduction, as metallic particles is widely used; however, because of their nobility, the stability of simple salt solutions is poor and hence they are suitably coordinated by several ligands. Thus, the electrodeposition of $\mathrm{Pd}^{\circ}$ is not simply an electrochemical process but it is associated with the coordination chemistry of the depositing metal ion [29]. Actually, the selection of a suitable palladium complex is a prerequisite for any reliable controlled $\mathrm{Pd}^{\circ}$ nanoparticle synthesis in aqueous solution [29-31] or for the formation of alloys [32]. The suitability of the complex is determined by its formation constant $\beta_{4}$ [30]. The metal-ligand interaction modifies the reduction potential of $\mathrm{Pd}^{2+}$, for instance shifting it to more cathodic values. The selection of the ligand should be such that the metal-ligand interaction is not too strong, but just enough to allow the discharge of metal ion at the cathode. Ammine complexes, e.g. $\left[\mathrm{Pd}\left(\mathrm{NH}_{3}\right)_{4}\right]^{2+}$, have the highest stability in basic media [33] and a $\beta_{4}$ constant of $10^{30.5}$. While the first and simplest Pd plating bath that operates in the acidic $\mathrm{pH}$ range is $\mathrm{PdCl}_{2}-\mathrm{HCl}$ system, where chloride complexes with different number of $\mathrm{Cl}^{-}$ions are formed [34], the $\left[\mathrm{PdCl}_{4}\right]^{2-}$ complex with moderate stability $\left(\beta_{4}=10^{12.2}\right)$ is susceptible to easy electrochemical reduction.

Thus, in this work we study the effect of the electrolyte properties (total metal concentration, type of palladium precursor), potential applied and deposition time on the morphological and chemical-physical properties of $\mathrm{CeO}_{2}$ and $\mathrm{Pd}-\mathrm{CeO}_{2}$ coatings, as-prepared and after calcination. The catalytic activity of calcined $\mathrm{Pd}-\mathrm{CeO}_{2}$ structured catalysts is evaluated in the $\mathrm{CO}$ oxidation. This reaction is considered a model reaction for environmental applications and it is usually adopted for the analysis of mass transfer performances since it is active at low temperature and does not produce intermediates. A comparison of the mass transfer performances of samples prepared with different deposition parameters is reported. The conversions in mass transfer are compared with the estimates provided from a correlation for the mass transfer in open cell foams and actually reveals some differences in the conversion that can be ascribed to incompletely coated surface or the local absence of the active phase that leads to deviations in the CO conversions.

\section{Experimental part}

\subsection{Catalyst preparation}

$9 \mathrm{~mm}$ disks of $\mathrm{FeCrAl}$ open-cell foams with a nominal cell size equal to $580 \mu \mathrm{m}$ (100 ppi) and with a thickness of $1.9 \mathrm{~mm}$, were cut from commercial panels from Alantum GMBH and used as structured supports. Prior to use, the foams were subsequently washed in acetone, water and then dried at $40{ }^{\circ} \mathrm{C}$ for $24 \mathrm{~h}$.

Electrodepositions were performed in a homemade double-compartment flow electrochemical cell using a potentiostat (Autolab, PGSTAT128 N, Eco Chemie) with GPES software. A Pt coil $(0.4 \mathrm{~mm}$ diameter and $40 \mathrm{~cm}$ in length) and a saturated calomel electrode (SCE) were used as counter and reference electrode (C.E. and R.E.), respectively. The working electrode (W.E.) was the FeCrAl foam disk and it was assembled by a two-pronged Pt electrical contact. The working and counter electrode compartments were separated by a glass frit. The R.E. was in electrolytic contact with the main compartment via a Luggin capillary placed $1 \mathrm{~mm}$ close to the surface of the foam cylinder. All potentials were reported with respect to SCE. The flow in the cell was set at $2 \mathrm{~mL} \mathrm{~min}^{-1}$ as reported in a previous work [35].

The electrolytes contained $\mathrm{Ce}\left(\mathrm{NO}_{3}\right)_{3}$ or a mixture of a Pd precursor [Pd $\left(\mathrm{NH}_{3}\right)_{4}\left(\mathrm{NO}_{3}\right)_{2}$ or $\mathrm{PdCl}$, noted as PdAN or PdC, respectively] and Ce( $\left(\mathrm{NO}_{3}\right)_{3}$ with atomic ratio (a.r.) $\mathrm{Pd} / \mathrm{Ce}=3 / 97$, to obtain a Pd nominal loading of $2 \mathrm{wt} . \%$ in the final catalyst. A given amount of $\mathrm{PdCl}_{2}$, calculated for $250 \mathrm{~mL}$ electrolyte solution, was firstly dissolved in $10 \mathrm{~mL}$ of distilled water with the addition of $0.1 \mathrm{~g}$ of concentrated $\mathrm{HCl}(37 \%)$ and kept under stirring and heating at $50^{\circ} \mathrm{C}$. When the solution became transparent orange colour, the rest of water and $\mathrm{Ce}\left(\mathrm{NO}_{3}\right)_{3}$ were added to obtain the electrolytic solution. The syntheses were performed varying the applied potential, concentration, and synthesis time in the range shown Table 1 . After synthesis, the samples were dried at $120^{\circ} \mathrm{C}$ for $24 \mathrm{~h}$ and calcined at $550^{\circ} \mathrm{C}$ for $10 \mathrm{~h}$.

Table 1

Synthesis parameters for the screening tests.

\begin{tabular}{|c|c|c|c|c|}
\hline Electrolyte & Concentration (M) & Initial $\mathrm{pH}$ & $\begin{array}{l}\text { Potential } \\
\text { (V vs SCE) }\end{array}$ & Time (s) \\
\hline $\mathrm{Ce}\left(\mathrm{NO}_{3}\right)_{3}$ & $0.06-0.15$ & $4.9-3.5$ & -1.1 to -1.35 & $500-2000$ \\
\hline PdAN: $\mathrm{Ce}\left(\mathrm{NO}_{3}\right)_{3}+\mathrm{Pd}\left(\mathrm{NH}_{3}\right)_{4}\left(\mathrm{NO}_{3}\right)_{2}$ & $0.06-0.15$ & $\sim 7$ & -1.1 to -1.35 & $500-2000$ \\
\hline PdC: $\mathrm{Ce}\left(\mathrm{NO}_{3}\right)_{3}+\mathrm{PdCl}_{2}(\mathrm{HCl})$ & $0.135-0.15$ & $\sim 2.5$ to 2.7 & -1.1 to -1.2 & $500-1000$ \\
\hline
\end{tabular}

$\mathrm{Pd} / \mathrm{Ce}=3 / 97$ atomic ratio. 
In order to study electrochemical properties of the electrolytes, linear sweep voltammetries (LSV) were performed in different aqueous electrolytes containing: i) only Pd precursor; ii) sole $\mathrm{Ce}\left(\mathrm{NO}_{3}\right)_{3}$; or iii) a mixture of them, but keeping the same concentration than in the cerium-containing electrolytes. The signal was recorded from 0 to $-1.4 \mathrm{~V} v s \mathrm{SCE}$ with a scan rate of $1 \mathrm{mV} \mathrm{s}^{-1}$.

\subsection{Characterization techniques}

Scanning electron microscopy (SEM) coupled with energy dispersive spectrometry (EDS) was performed by using an EP EVO 50 Series Instrument (EVO ZEISS) equipped with an INCA X-act Penta FET ${ }^{\circledast}$ Precision EDS microanalysis and INCA Microanalysis Suite Software (Oxford Instruments Analytical). The accelerating voltage was $20 \mathrm{kV}$ and spectra were collected for $60 \mathrm{~s}$. As-prepared deposited and calcined foams were analysed in 3-4 regions of interest. The average $\mathrm{Pd} / \mathrm{Ce}$ a.r. ratio values were estimated for five different foams. The thickness of the coated layers was estimated from SEM images where the solid developed cracks.

During SEM/EDS analysis, Micro-Raman spectra were in situ recorded by a Renishaw Raman Invia spectrometer configured with a Leica DMLM microscope using $\mathrm{Ar}^{+}$laser source $(\lambda=514.5 \mathrm{~nm}$, $\mathrm{P}_{\text {out }}=30 \mathrm{~mW}$ considering the decrease in power due to the plasma filter). The laser power was set by $10 \%$ of the source and the signal was accumulated by four individual spectra with an acquisition time of $10 \mathrm{~s}$.

The X-ray diffraction (XRD) analysis of the film grown on the foam was carried out using a PANalytical X'Pert diffractometer equipped with a copper anode $\left(\lambda_{\text {mean }}=0.15418 \mathrm{~nm}\right)$ and a fast X'Celerator detector. Wide-angle diffractogram was collected over $2 \theta$ range from 20 to $70^{\circ}$ with a step size of $0.05^{\circ}$ and counting time $50 \mathrm{~s}$.

$\mathrm{N}_{2}$ adsorption-desorption isotherms were measured at $-196^{\circ} \mathrm{C}$ using a Micromeritics ASAP 2020 instrument. Prior to each measurement, two calcined foams were degassed via a two-step pretreatement: $150{ }^{\circ} \mathrm{C}$ for $30 \mathrm{~min}$ under a pressure of $30 \mu \mathrm{mHg}$ and then $250{ }^{\circ} \mathrm{C}$ for $30 \mathrm{~min}$. The specific surface area $\left(\mathrm{S}_{\mathrm{BET}}\right)$ was calculated using the Brunauer-Emmett-Teller (BET) multiple-point method in the relative pressure range $\mathrm{p} / \mathrm{p}_{\mathrm{o}}$ from 0.05 to 0.3 .

Temperature programmed reduction by Hydrogen $\left(\mathrm{H}_{2}\right.$-TPR) was performed in an AutoChem II (Chemisorption analyzer, Micromeritics) with one coated foam. The catalyst was firstly outgassed at $150{ }^{\circ} \mathrm{C}$ under $30 \mathrm{~mL} \mathrm{~min}^{-1}$ of $\mathrm{He}$ for $30 \mathrm{~min}$. After cooling to $-10^{\circ} \mathrm{C}$ by vapor of liquid $\mathrm{N}_{2}$, the carrier gas was switched to $5 \% \mathrm{H}_{2} / \mathrm{Ar}(\mathrm{v} / \mathrm{v})$ at $30 \mathrm{~mL}$ $\min ^{-1}$. When the baseline was stable, the temperature was increased to $900{ }^{\circ} \mathrm{C}$ with a ramp of $10^{\circ} \mathrm{C} \mathrm{min}^{-1}$, while the amount of $\mathrm{H}_{2}$ consumed was measured by means of a thermal conductivity detector (TCD).

\subsection{Catalytic tests}

The samples with a diameter equal to $9 \mathrm{~mm}$ were loaded in a pipe with internal diameter of $9 \mathrm{~mm}$ and external diameter of $11 \mathrm{~mm}$ [28]. This pipe was then inserted in a threaded tubular reactor fixed with a screw and placed in an oven. At the top and at the bottom of the catalytic samples, two $1200 \mu \mathrm{m}$ and a single $580 \mu \mathrm{m}$ bare foam disks respectively, were added in order to increase the bed length and avoid inlet effects acting as flow distributors. Two K-type thermocouples were inserted in the reactor to measure the temperature upstream and downstream the catalytic bed. Carbon monoxide and air provided by SAPIO $^{\circledR}$ were fed through stainless steel lines and regulated with BROOKS mass flow controllers; gases were mixed and preheated in a coil up to $175^{\circ} \mathrm{C}$ before entering in the reaction zone. Compositions of reactants and products were analysed with an on-line gas chromatograph 6890 from Agilent Technologies equipped with two thermal conductivity detectors (TCD) and two packed columns filled respectively with Molecular Sieve 5 A 80/100 mesh and Porapak Q 80/100; the first column was used for the quantification of nitrogen, oxygen and carbon monoxide, the second one was exploited for the evaluation of
$\mathrm{CO}_{2}$; temperature profile of the GC oven was chosen accordingly to provide adequate separation of the peaks in the chromatograms.

Effects of the flow rates on the $\mathrm{CO}$ combustion were assessed investigating different flow rates in the range $1000-9000 \mathrm{~cm}^{3} \mathrm{~min}^{-1}$ at STP (1-9 SLM) with 3\% CO (v/v). During each test the oven temperature was increased stepwise in order to change the inlet temperature, after reaching steady state conditions for the temperatures, the conversion of $\mathrm{CO}$ was determined by the analysis of the reaction products; the overall errors detected in carbon balances were in the range $1-3 \%$. Only analyses before the proper ignition point or in the plateau regime when the reaction is almost under complete diffusive control were performed, due to the problematic control of the temperature in the kinetically-limited regime. Due to the exothermic character of the reaction, temperature differences up to $120^{\circ} \mathrm{C}$ across the foam bed were observed in the achieved mass transfer regime, much lower than adiabatic temperature rise, i.e. $300{ }^{\circ} \mathrm{C}$ in the testing conditions, due to efficient heat transfer mechanisms inside open cell foams. Blank tests with calcined bare foams were carried out to confirm the absence of homogeneous reaction and avoid any effect in the conversion induced by the setup or the bare supports. The conversions lower than $4 \%$ were observed up to $450^{\circ} \mathrm{C}$. Absence of bypass was checked performing the tests at 1 SLM: in these conditions almost complete conversions were observed confirming the absence of preferential flow paths in the reactor.

\section{Results and discussion}

\section{1. $\mathrm{CeO}_{2}$ electrodeposition and calcined samples}

The parameters that determined the electrochemical $\mathrm{pH}$ generation and the chemical precipitation of cerium-based deposits (i.e. electrolyte concentration, potential applied, and synthesis time) were modified as shown in Table 1.

LSVs in the different $\mathrm{Ce}\left(\mathrm{NO}_{3}\right)_{3}$ electrolytes in Fig. S1 displayed a discharge at ca $-1.1 \mathrm{~V}$ due to $\mathrm{NO}_{3}{ }^{-}$reduction [21], which overlapped with $\mathrm{H}_{2} \mathrm{O}$ reduction at potentials above $-1.2 \mathrm{~V}$. The increase in concentration slightly shifted the onset towards more cathodic potentials and decreased the current at high cathodic potentials, due to the inhibition of the $\mathrm{H}_{2} \mathrm{O}$ reduction. Thus, in this work the generation of the $\mathrm{pH}$ was mainly related to $\mathrm{NO}_{3}{ }^{-}$reduction, with some contribution of $\mathrm{H}_{2} \mathrm{O}$ reduction, the reduction of dissolved $\mathrm{O}_{2}$ at low potential could not be also discarded.

To investigate the feasibility of the method to prepare thin and thick cerium-containing layers, electrodepositions were firstly performed at $-1.2 \mathrm{~V}$ with a $0.06 \mathrm{M} \mathrm{Ce}\left(\mathrm{NO}_{3}\right)_{3}$ solution in the $500-2000 \mathrm{~s}$ range. The current exchanged, Fig. S2a, quickly decreased in the first $250 \mathrm{~s}$, reaching then the limiting value with a high reproducibility. The evolution of the mass of solid electrodeposited with the time followed a linear behaviour, Fig. S3, reaching a $32.5 \mathrm{wt} . \%$ in 2000 s. This trend indicates that the electrodeposition yield was relatively constant even after $2000 \mathrm{~s}$ [14,22]. Moreover, it could be stated that the previously reported hindering effect of the first deposited layers (reducing the electronic conductivity at the interface with the solution) and the establishment of an equilibrium between the electrodeposition phenomenon and the acidic redissolution at the deposit-solution interface [20] did not greatly modify the electrodeposition in this work.

SEM images of the foams coated at different times are shown in Fig. 1. Even at $500 \mathrm{~s}$, the foam surface was covered by a very thin and compact film, which did not alter its typical ball morphology (Fig. 1a, a1). It was not possible to identify any particle shape in the coating, probably because of the formation of very small particles out of SEM resolution. In agreement with solid loadings, the coating thickness homogeneously increased with the length of the pulse. At $1000 \mathrm{~s}$ (Fig. 1b, b1), the bare foam shape could be still observed, while at 2000 $\mathrm{s}$, a ca. $18 \mu \mathrm{m}$ film precipitated (Fig. 1c, c1). The increase in the coating thickness was accompanied by the development of cracks and spalling, 

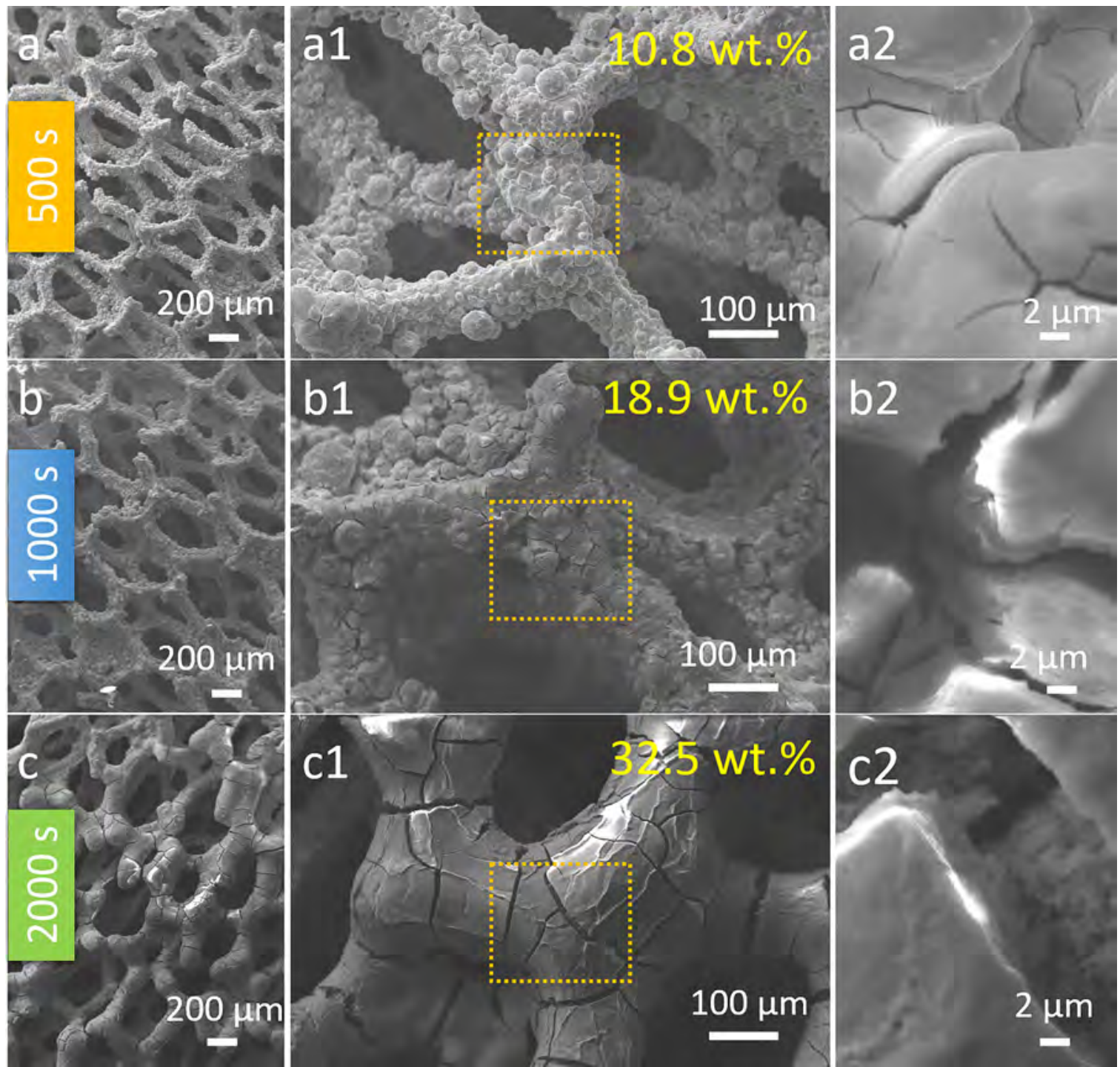

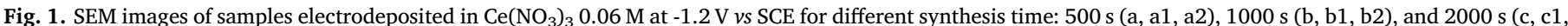

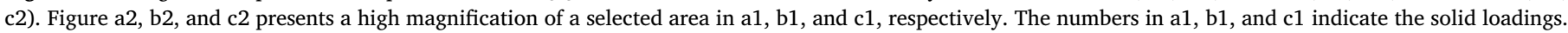

but the morphology of the coating was unaltered (Fig. 1b2, c2).

The concentration of both electroactive $\mathrm{NO}_{3}{ }^{-}$anions and precipitating $\mathrm{Ce}^{3+}$ cations increased in $0.12,0.135$, and $0.15 \mathrm{M}$ electrolytes. However, the current exchanged during the pulse at $-1.2 \mathrm{~V}$, only increased with the concentration up to ca. $150-155 \mathrm{~mA}$ at $500 \mathrm{~s}$ (Fig. S2b), suggesting the saturation of the active sites for the reduction [36]. Consequently, the solid loading was not directly related to the electrolyte concentration, for instance at $1000 \mathrm{~s}$ a $16-19 \mathrm{wt} \%$ deposited with $0.06-0.135 \mathrm{M}$ electrolytes (Fig. 1b1, 2a, 2b). In contrast, the coating morphology, particle shape and size, was altered. In comparison to the $0.06 \mathrm{M}$ solution, well-defined platelets precipitated (Fig. 2a2, b2, c2); the higher the concentration the smaller the particles. Moreover, a compact outer layer developed as the synthesis time was prolonged, being more abundant and thicker in coatings obtained from 0.135 and $0.15 \mathrm{M}$ electrolytes, despite for the latter the synthesis time was only $500 \mathrm{~s}$ (Fig. 2a1, b1, c1). By modifying the potential between $-1.1 \mathrm{~V}$ to $-1.35 \mathrm{~V}$ similar morphologies could be obtained (not shown), although the current increased by performing the syntheses at $-1.35 \mathrm{~V}$ (Fig. S2b).

In previous works $[14,16]$, platelets were attributed to $\mathrm{Ce}(\mathrm{OH})_{3}$ that establishes hydrogen bonds, while spherical particles to $\mathrm{CeO}_{2}$. However, in this work, regardless of the investigated parameters, the only deposited crystalline phase identified by XRD was the cubic fluorite $\mathrm{CeO}_{2}$ (Fig. 3a). In the Raman spectra in Fig. 3c, the positions of the bands due to the $\mathrm{F}_{2 \mathrm{~g}}$ of $\mathrm{CeO}_{2}\left(456 \mathrm{~cm}^{-1}\right)$ and defects $\left(600 \mathrm{~cm}^{-1}\right)$ were unaltered with the deposition parameters. Furthermore, the peak observed at $1040-1050 \mathrm{~cm}^{-1}$ was due to free nitrate [15].

The samples were calcined at $550{ }^{\circ} \mathrm{C}$ to remove the nitrates and physisorbed water and to stabilize the coating for medium temperature catalytic applications. In Fig. S4, SEM images of selected representative samples at different magnifications are shown. The morphology of the coating particles was not largely altered, although some more cracks developed. Similar to the as-deposited samples, only the reflections of $\mathrm{CeO}_{2}$ and the metallic support were identified in the XRD patterns, Fig. 3b. Raman spectra in Fig. 3d, confirmed the removal of nitrates, and they also indicated that the $\mathrm{CeO}_{2}$ was slightly more crystalline (more intense and narrower $\mathrm{F}_{2 \mathrm{~g}}$ mode), but kept some defects (band at ca. $600 \mathrm{~cm}^{-1}$ ). The amount of adsorbed $\mathrm{N}_{2}$ was correlated to the solid loading (Fig. S5), $\mathrm{S}_{\mathrm{BET}}$ values of coated foams increased from 7.5, 10.8 to $11.2 \mathrm{~m}^{2} \mathrm{~g}^{-1}$ for the samples prepared in $\mathrm{Ce}\left(\mathrm{NO}_{3}\right)_{3} 0.06 \mathrm{M}$ at $-1.2 \mathrm{~V}$ for 500,1000 , and $2000 \mathrm{~s}$, respectively. In the $\mathrm{H}_{2}$-TPR profiles of calcined foams coated with $0.06 \mathrm{M}$ and $0.15 \mathrm{M}$ electrolytes (Fig. 4), the $\mathrm{H}_{2}$ consumption due to surface and bulk $\mathrm{CeO}_{2}$ were recorded at medium and high temperatures, respectively [37]. The profile was shifted 


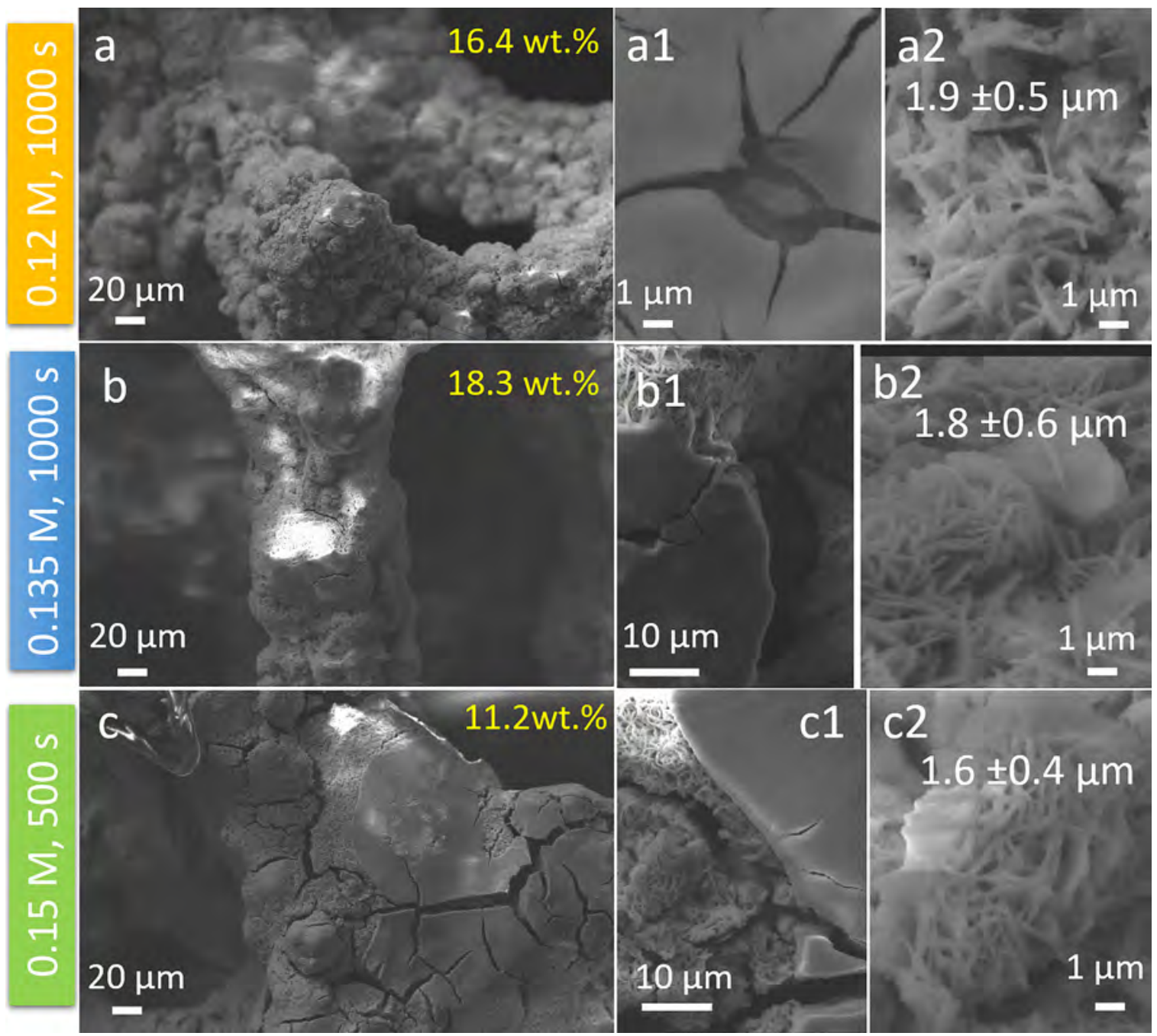

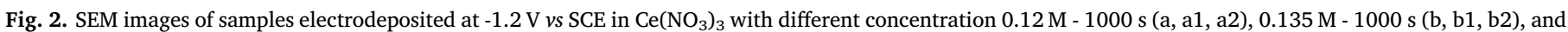

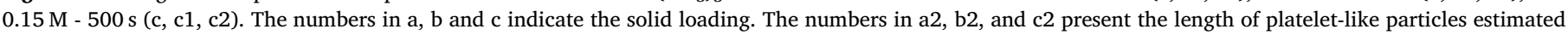
from high magnification images.

towards lower temperatures for the sample obtained from the $0.06 \mathrm{M}$ electrolyte, the shift being more remarkable for the reduction of surface $\mathrm{CeO}_{2}$. These differences could be related to the surface area of the coatings as well as the accessibility of $\mathrm{H}_{2}$ to the sites related to the morphology of the particles.

\section{2. $\mathrm{Pd}-\mathrm{CeO}_{2}$ electrodeposition and calcined samples}

The wide range of parameters suitable for the deposition of $\mathrm{CeO}_{2}$ coatings were exploited in the preparation of $\mathrm{Pd}_{-}-\mathrm{CeO}_{2}$. The aim was to promote the $\mathrm{NO}_{3}{ }^{-}$reduction to allow the precipitation of $\mathrm{Pd}^{2+}$ together with $\mathrm{CeO}_{2}$, as in the conventional coprecipitation process with $\mathrm{NaOH}$ [38], avoiding the massive $\mathrm{Pd}^{2+}$ electroreduction. To achieve this aim, the chemistry and electrochemistry of $\mathrm{Pd}^{2+}$ were taken into account. Namely, $\left[\mathrm{Pd}\left(\mathrm{NH}_{3}\right)_{4}\right]\left(\mathrm{NO}_{3}\right)_{2}$ or $\mathrm{PdCl}_{2}-\mathrm{HCl}$ were mixed with $\mathrm{Ce}$ $\left(\mathrm{NO}_{3}\right)_{3}$ to prepare the electrolytes. The differences between both electrolytes were not only the $\mathrm{Pd}^{2+}$ reducibility but also the initial $\mathrm{pH}$ as shown in Table 1. It should be remarked that the interfacial reduction reaction between $\mathrm{Pd}^{2+}$ and $\mathrm{Ce}^{3+}$, which has been reported to occur after mixing $\mathrm{Ce}^{3+}$ precursor with $\mathrm{Pd}^{2+}$ and ammonia [39], could not be discarded to contribute to the formation of $\mathrm{Pd}^{\circ}$ particles.

Firstly, the complexes in the electrolyte solutions were investigated by UV-vis spectroscopy (Fig. S6). The spectra of the electrolytes were compared with those of aqueous solutions of sole $\mathrm{Ce}\left(\mathrm{NO}_{3}\right)_{3}$, $\left[\mathrm{Pd}\left(\mathrm{NH}_{3}\right)_{4}\right]$
$\left(\mathrm{NO}_{3}\right)_{2}$, and $\mathrm{PdCl}_{2}$ in $\mathrm{HCl}$ with the same concentration than in Cecontaining electrolytes. The band at $298 \mathrm{~nm}$ of the square planar [Pd $\left.\left(\mathrm{NH}_{3}\right)_{4}\right]^{2+}$ complex [33] was overlapped with a band of the $\mathrm{Ce}\left(\mathrm{NO}_{3}\right)_{3}$ solution. On the other hand, the spectra of $\mathrm{PdCl}_{2}$ in $\mathrm{HCl}$ showed a spinforbidden d-d transition $\left({ }^{1} \mathrm{~A}_{2 \mathrm{~g}} \longleftarrow{ }^{1} \mathrm{~A}_{1 \mathrm{~g}}\right)$ at $430 \mathrm{~nm}$ that could be related to the square-planar $\left[\mathrm{PdCl}_{3}\right]\left[\mathrm{H}_{2} \mathrm{O}\right]^{-}$complex, rather than to $\left[\mathrm{PdCl}_{4}\right]^{2-}$ [40]. The band slightly shifted towards lower wavenumbers $(426 \mathrm{~nm})$ in the Ce-containing electrolyte.

The differences in the $\mathrm{Pd}^{2+}$ reduction depending on the electrolyte were evidenced by LSV curves in Fig. S7. In the ammine containing electrolyte, the small reduction peak starting at ca. $-0.7 \mathrm{~V}$ was related to the two-electron $\mathrm{Pd}^{2+}$ reduction in $\left[\mathrm{Pd}\left(\mathrm{NH}_{3}\right)_{4}\right]^{2+}[41]$. The same peak was observed in absence of $\mathrm{Ce}^{3+}$. These results confirmed the presence of the square planar complex, not clearly supported by UV-vis spectroscopy. The current registered at more negative potentials could be related to both nitrate and water reduction promoted by $\mathrm{Pd}^{\circ}$. In the $\mathrm{PdCl}_{2}-\mathrm{HCl}$ electrolyte, the reduction already started at $-0.3 \mathrm{~V}$, due to the lower stability of $\left[\mathrm{PdCl}_{3}\right]\left[\mathrm{H}_{2} \mathrm{O}\right]^{-}$[34]. During electrodeposition, the increase of the $\mathrm{pH}$ and the production of $\mathrm{NH}_{4}{ }^{+}$in the electrodeelectrolyte interface may modify these complexes; although the replenishment of the solution due to the flow of the electrolyte may decrease this behaviour.

Performing the electrodepositions at $-1.2 \mathrm{~V} v s$ SCE in the electrolyte containing the $\left[\mathrm{Pd}\left(\mathrm{NH}_{3}\right)_{4}\right]^{2+}$ complex, the screening of synthesis 

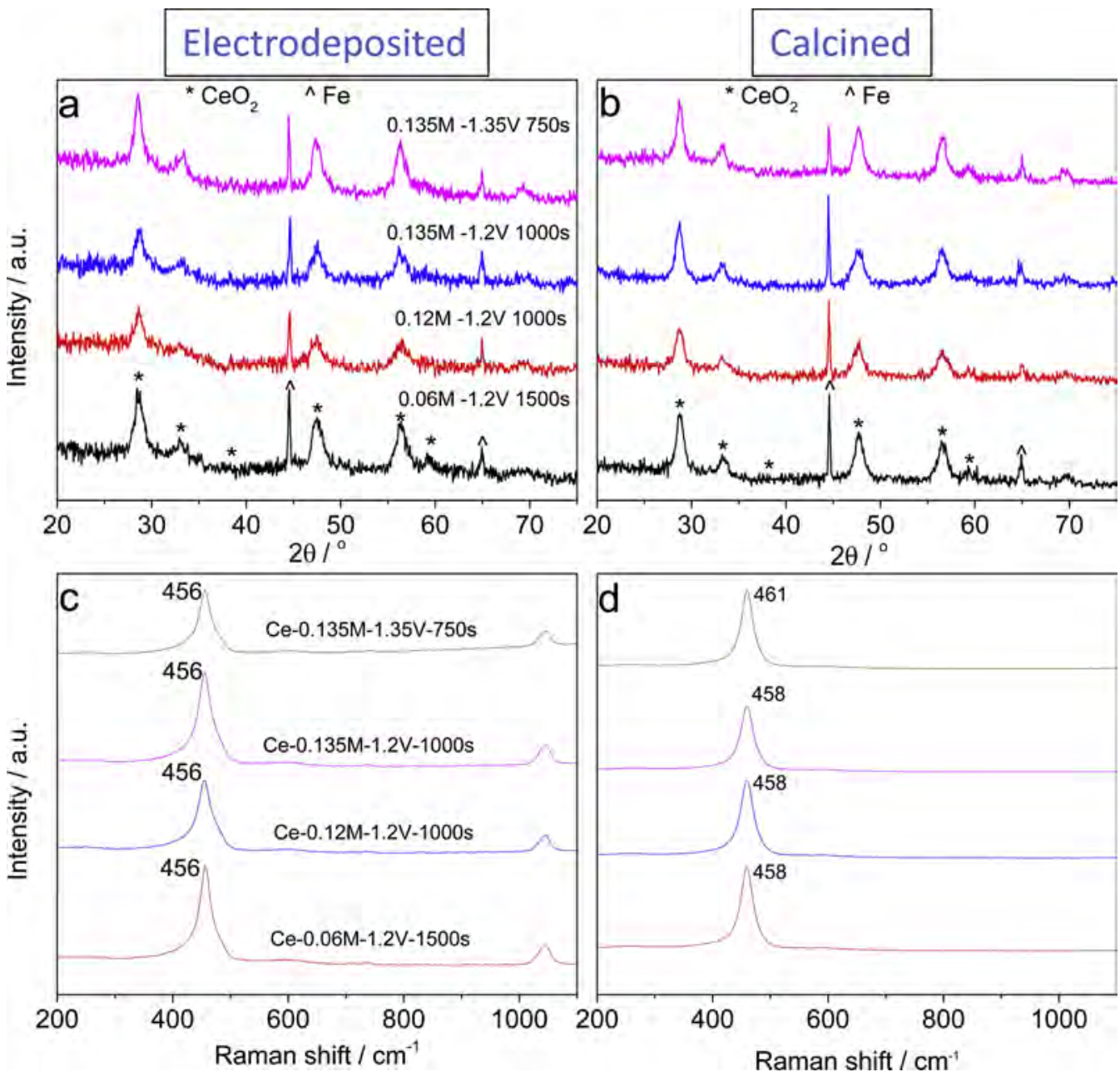

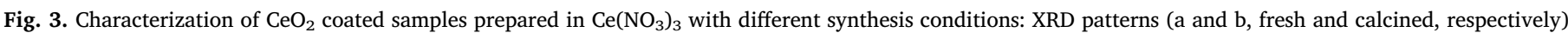
and Raman spectra (c and d, fresh and calcined, respectively).

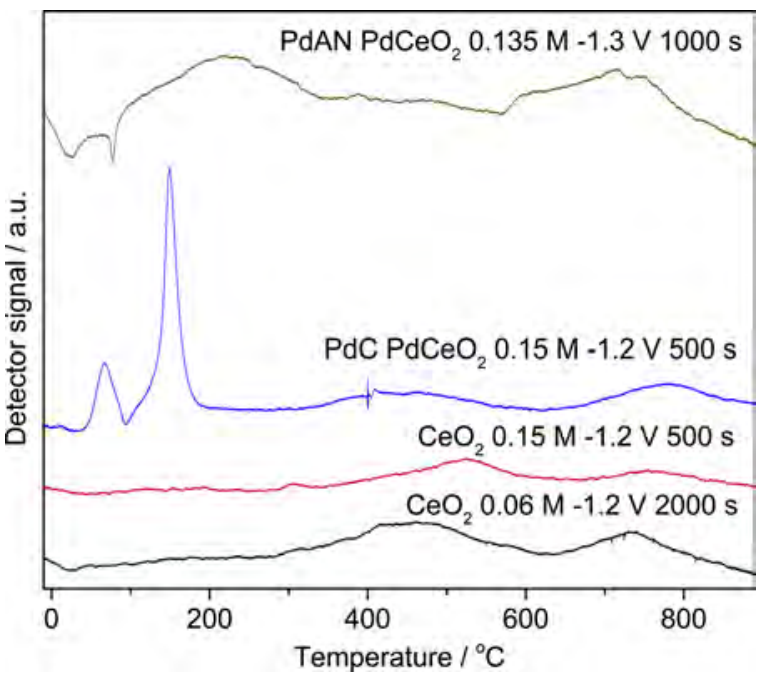

Fig. 4. $\mathrm{H}_{2}$-TPR of $\mathrm{CeO}_{2}$ and $\mathrm{Pd}-\mathrm{CeO}_{2}$ calcined foams obtained from both ammine (PdAN) and chloride (PdC) complexes. The synthesis conditions for every sample are shown in the plot.

parameters, i.e. time (500-2000 s) and concentration (0.06-0.15 M), revealed a good solid coverage but with a poor Pd distribution. The foam was well covered by a film mainly made of platelets notwithstanding the thickness (Fig. 5a, a1, a2), unlike for pristine $\mathrm{CeO}_{2}$ samples. The highest $\mathrm{pH}$ of the electrolyte could modify the electrodeposition process (nucleation and growth) and therefore the particle morphology. As shown in Fig. 5 a2, agglomerates of Pd-containing particles were identified in some regions of the sample $(\mathrm{Pd} / \mathrm{Ce}=14.1$ / 85.9 a.r.), while the Pd content dispersed on the coating, i.e. identified by EDS but not as particles, was very low (e.g. $\mathrm{Pd} / \mathrm{Ce}=0.6 / 99.4$ a.r.). The stability of the complex and the simultaneous production of $\mathrm{NH}_{4}{ }^{+}$ during the nitrate reduction may inhibit $\mathrm{Pd}^{2+}$ precipitation as oxide/ hydroxide or $\mathrm{Pd}^{\circ}$.

A more cathodic potential, $-1.3 \mathrm{~V}$ vs SCE, combined with a $0.135 \mathrm{M}$ electrolyte slightly increased the Pd loading dispersed in the solid, e.g. $\mathrm{Pd} / \mathrm{Ce}=1.1 / 98.9$ a.r., without modifying the coating morphology (Fig. 5b, b1, b2). Short times, i.e. $1000 \mathrm{~s}$, were however required to limit the growth of Pd-containing particles and $\mathrm{H}_{2}$ evolution by water reduction. Under these conditions a faster basic media generation could be fostered because of the more negative potential (Fig. S8a), while the highest $\mathrm{NO}_{3}{ }^{-}$concentration suppressed the $\mathrm{H}_{2}$ evolution, at least at short times. Indeed, at the same potential a lower electrolyte concentration gave rise to more cracked deposits, because the larger contribution of $\mathrm{H}_{2}$ evolution. A more concentrated $0.15 \mathrm{M}$ solution led to a good coverage with less and smaller cracks (Fig. 5c, c1), but promoted the deposition of big Pd spherical particles of even up to $1 \mu \mathrm{m}$ (Fig. 5c2).

The easiest reducibility of the $\left[\mathrm{PdCl}_{3}\right]\left[\mathrm{H}_{2} \mathrm{O}\right]^{-}$complex made it necessary to adjust the potential applied (Fig. 6 and Fig. S8b). Moreover, concentrated electrolytes (i.e. 0.135 and $0.15 \mathrm{M}$ ) were preferred to: i) favor the $\mathrm{Pd}^{2+}$ precipitation; ii) decrease synthesis time; iii) 


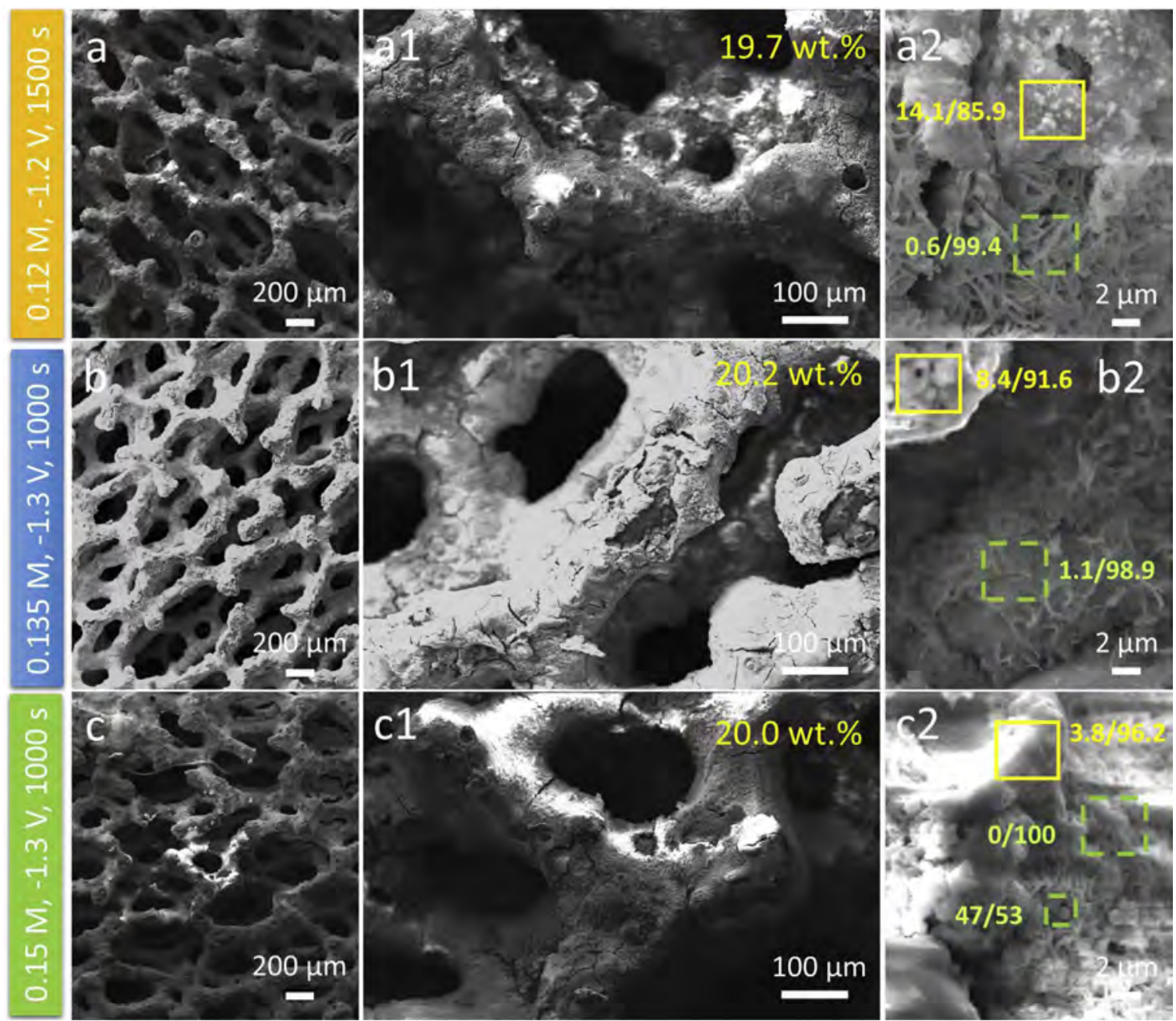

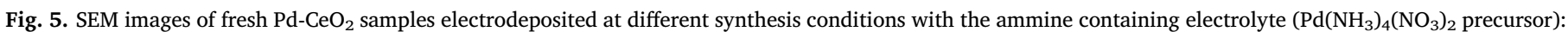

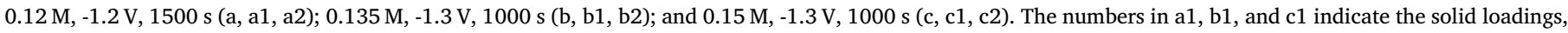
and in $\mathrm{a} 2, \mathrm{~b} 2, \mathrm{c} 2$ the $\mathrm{Pd} / \mathrm{Ce}$ ratio estimated from EDS.

achieve a suitable loading. In comparison to the $\left[\mathrm{Pd}\left(\mathrm{NH}_{3}\right)_{4}\right]^{2+}$ complex, with the $0.135 \mathrm{M}$ electrolyte and performing the synthesis for $1000 \mathrm{~s}$, the co-deposition of large $\mathrm{Pd}^{\circ}$ particles and $\mathrm{CeO}_{2}$ compact and platelet-containing layers occurred at -1.3 and $-1.2 \mathrm{~V} v s$ SCE (Fig. 6b, b1, b2). The acidic $\mathrm{pH}$ of the solution may alter the $\mathrm{CeO}_{2}$ precipitation in comparison to the $\left[\mathrm{Pd}\left(\mathrm{NH}_{3}\right)_{4}\right]^{2+}$ containing electrolyte. Moreover, the exchange of $\mathrm{Cl}^{-}$by $\mathrm{H}_{2} \mathrm{O}$ during the electro-base generation method could occur as the $\mathrm{pH}$ increased [40], with the modification of the reduction potential [42]. By performing the deposition at a less negative $-1.1 \mathrm{~V}$ vs SCE potential (Fig. 6a, a1, a2), the $\mathrm{Pd}^{\circ}$ deposition was partially suppressed and the solid contained some more well dispersed Pd, with $\mathrm{Pd} / \mathrm{Ce}$ a.r around 3.4/96.6 and 1.0/99.0 for instance.

The increase in the concentration of the electrolyte containing $\left[\mathrm{PdCl}_{3}\right]\left[\mathrm{H}_{2} \mathrm{O}\right]^{-}$to $0.15 \mathrm{M}$ controlled better the deposition of the solid at $-1.2 \mathrm{~V}$, whenever a short time was used, i.e. $500 \mathrm{~s}$ as shown in Fig. $6 \mathrm{c}$, c1, c2. If prolonging the time up to $1000 \mathrm{~s}$, the growth of Pd particles was favored. In the $500 \mathrm{~s}$ synthesis, $\mathrm{CeO}_{2}$ deposits with $\mathrm{Pd} / \mathrm{Ce}=3.3$ / 96.7 a.r. were prepared. Only in some isolated regions were identified agglomerates of Pd particles, making the Pd content measured in dissolved coatings to be larger ( $\mathrm{Pd} / \mathrm{Ce}=5 / 95$ a.r.) [28]. It should be remarked that the solid loading was larger in comparison to the $\mathrm{CeO}_{2}$ and the $\mathrm{Pd}-\mathrm{CeO}_{2}$ samples prepared with the ammine complex.

After calcination, the coating of the samples prepared with the ammine complex developed less cracks and the film was well adhered, since the single platelet morphology better withstand the shearing stresses (Fig. 7a, a1). While in coatings obtained from the acidic chlorine electrolyte some partial detachment of the more compact film occurred (Fig. 7b, b1). Nevertheless, in both cases the foam surface was well coated. No large sintering of the Pd-containing particles was observed by SEM, and dispersed Pd species, i.e. identified by EDS but not as particles, were still present in the catalysts prepared from both type of Pd precursors.

Likewise $\mathrm{CeO}_{2}$, and regardless of the coating morphology, XRD patterns only showed the $\mathrm{CeO}_{2}$ reflections in all of the samples before and after calcination (Fig. 8a shows the calcined samples), even in those where the formation of large Pd-containing particles was evidenced by SEM/EDS. It was rather difficult to establish any difference among the patterns before and after calcination and to observe any shift in the reflections due to $\mathrm{Pd}^{2+}$ inclusion in the structure. Micro-Raman measurements inside the SEM chamber completed the structural characterization. In Fig. 8b the spectra of some representative calcined samples are shown. The intensity and width of bands due to the $\mathrm{CeO}_{2}$ $\mathrm{F}_{2 \mathrm{~g}}$ mode and defects depended on coating features such as composition and thermal treatment. A larger amount of well-dispersed Pd species, like in PdC samples, was correlated with a more intense band at ca. $550 \mathrm{~cm}^{-1}$ due to defects and with a lower sintering during calcination (broader $\mathrm{F}_{2 \mathrm{~g}}$ mode), probably due to the formation of the $\mathrm{Pd}_{\mathrm{x}} \mathrm{Ce}_{1-\mathrm{x}} \mathrm{O}_{2-\delta}$ solid solution, as identified by XPS in our previous work [28]. The $\mathrm{B}_{1 \mathrm{~g}}$ vibrational mode of square planar $\left[\mathrm{PdO}_{4}\right]$ subunits in the structure of $\mathrm{PdO}$ was also registered at $651 \mathrm{~cm}^{-1}$. This band was present in as- 


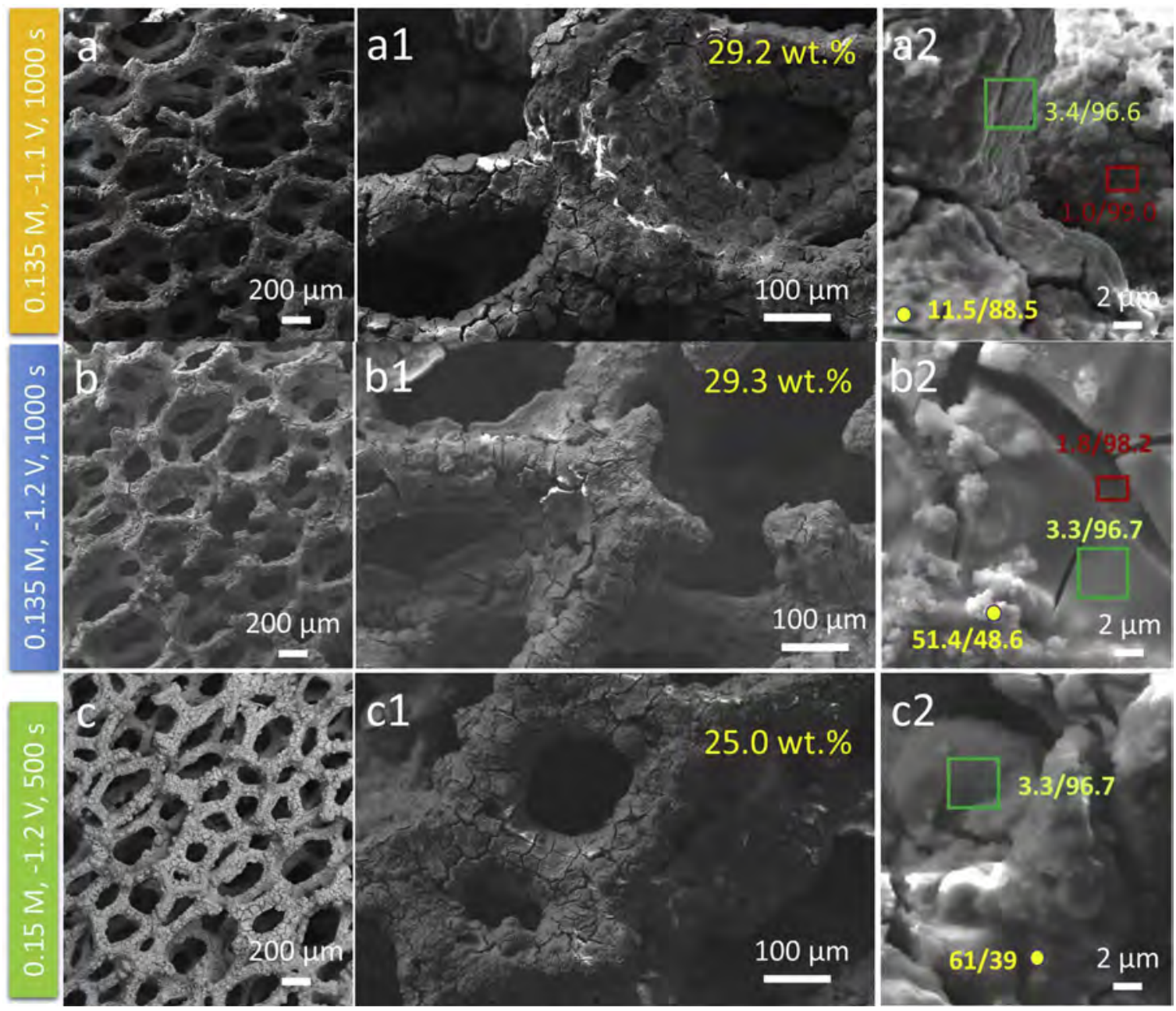

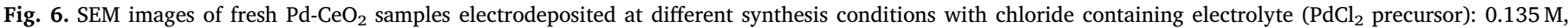

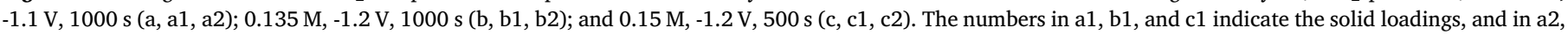
$\mathrm{b} 2, \mathrm{c} 2$ the $\mathrm{Pd} / \mathrm{Ce}$ ratio estimated from EDS.

deposited samples prepared in $1000 \mathrm{~s}$ with both 0.135 and $0.15 \mathrm{M}$ ammine-containing electrolytes at $-1.3 \mathrm{~V}$ and with the $0.135 \mathrm{M}$ chloride one applying a -1.2 and $-1.3 \mathrm{~V}$, in places wherein large Pd-containing species were observed by SEM/EDS such as in Fig. 5b2, c2 or Fig. 6a2, b2. It suggested that both large $\mathrm{Pd}^{\circ}$ and $\mathrm{PdO}$ particles precipitated during electrodeposition. On the other hand, when absent in the fresh samples, a small PdO band developed after calcination due to some sintering. These results, supported by previous XPS measurements in PdC $0.15 \mathrm{M}-1.2 \mathrm{~V} 500 \mathrm{~s}$ calcined sample, indicated that the catalysts contained $\mathrm{Pd}_{\mathrm{x}} \mathrm{Ce}_{1-\mathrm{x}} \mathrm{O}_{2-\delta}, \mathrm{Pd}^{\circ}$ and $\mathrm{PdO}$. The solid solution seemed to be more abundant in PdC samples due to well dispersed $\mathrm{Pd}^{2+}$, this phase coexisted with $\mathrm{Pd}^{\circ}$ and PdO. In PdAN catalysts, the lower amount of Pd decreased the amount of solid solution and $\mathrm{PdO}$, but $\mathrm{Pd}^{\circ}$ particles were observed.

The $\mathrm{H}_{2}$-TPR profiles of selected samples prepared with ammine and chloride complexes were displayed in Fig. 4. In the profile of sample prepared with the $0.135 \mathrm{M}$ ammine electrolyte at $-1.3 \mathrm{~V}$ for $1000 \mathrm{~s}$, a negative peak due to the decomposition of palladium hydride, formed on large $\mathrm{Pd}^{\circ}$ particles, was recorded at ca. $80^{\circ} \mathrm{C}[43,44]$. The broad peak in the $100-350{ }^{\circ} \mathrm{C}$ range could be attributed to the reduction of well dispersed $\mathrm{Pd}^{2+}$ species, such as those in the $\mathrm{Pd}_{\mathrm{x}} \mathrm{Ce}_{1-\mathrm{x}} \mathrm{O}_{2-\delta}$ solid solution, together with surface $\mathrm{CeO}_{2}$ [44]. Indeed, the intensity of the reduction of surface $\mathrm{CeO}_{2}$ decreased and was registered at lower temperatures in comparison to sole $\mathrm{CeO}_{2}$. The reduction profile of the catalyst prepared with the $0.15 \mathrm{M}$ chloride-containing electrolyte was modified in agreement with the different properties. PdO and $\mathrm{Pd}^{2+}$ in the solid solution identified in our previous work [28], were responsible of the reduction peaks at ca. 70 and $150^{\circ} \mathrm{C}$, the latter also overlapped with the $\mathrm{CeO}_{2}$ reduction. While the lower number of $\mathrm{Pd}^{\circ}$ or their smaller size were responsible of the absence of the negative peak.

\subsection{Catalytic activity in the $\mathrm{CO}$ oxidation}

The CO ignition curves obtained over coated foams prepared with the two $\mathrm{Pd}^{2+}$ precursors with a 3\% CO inlet concentration and at selected SLM flows are shown in Fig. 9. The detailed tests performed at all the flow rates in the range from 1 to 9 SLM are shown in Fig. S9. Tests at 1 SLM were performed to exclude any preferential flow path inside the reactor; almost complete conversion was observed ensuring adequate activity of the catalyst and excluding a significant bypass.

At 3 SLM, the catalyst prepared in the $0.135 \mathrm{M}$ ammine electrolyte at $-1.3 \mathrm{~V}$ for $1000 \mathrm{~s}$, namely the one showing the best characterization features, had an ignition temperature around $215^{\circ} \mathrm{C}$ and reached an $89 \%$ CO conversion in the external diffusional regime. A slightly lower CO conversion ( $88 \%$ ) was achieved over the catalyst prepared at $-1.2 \mathrm{~V}$. However, after the ignition point, the plateau was reached more slowly and at a higher temperature, i.e. $325^{\circ} \mathrm{C}$. In the curves obtained with catalysts prepared from chloride electrolytes, lower ignition temperatures and higher CO conversions in the diffusive regime, above $92 \%$, were achieved. Variations of only $1-2 \%$ in the CO conversion and ca. $25^{\circ} \mathrm{C}$ in the temperature were observed depending on the synthesis conditions. 

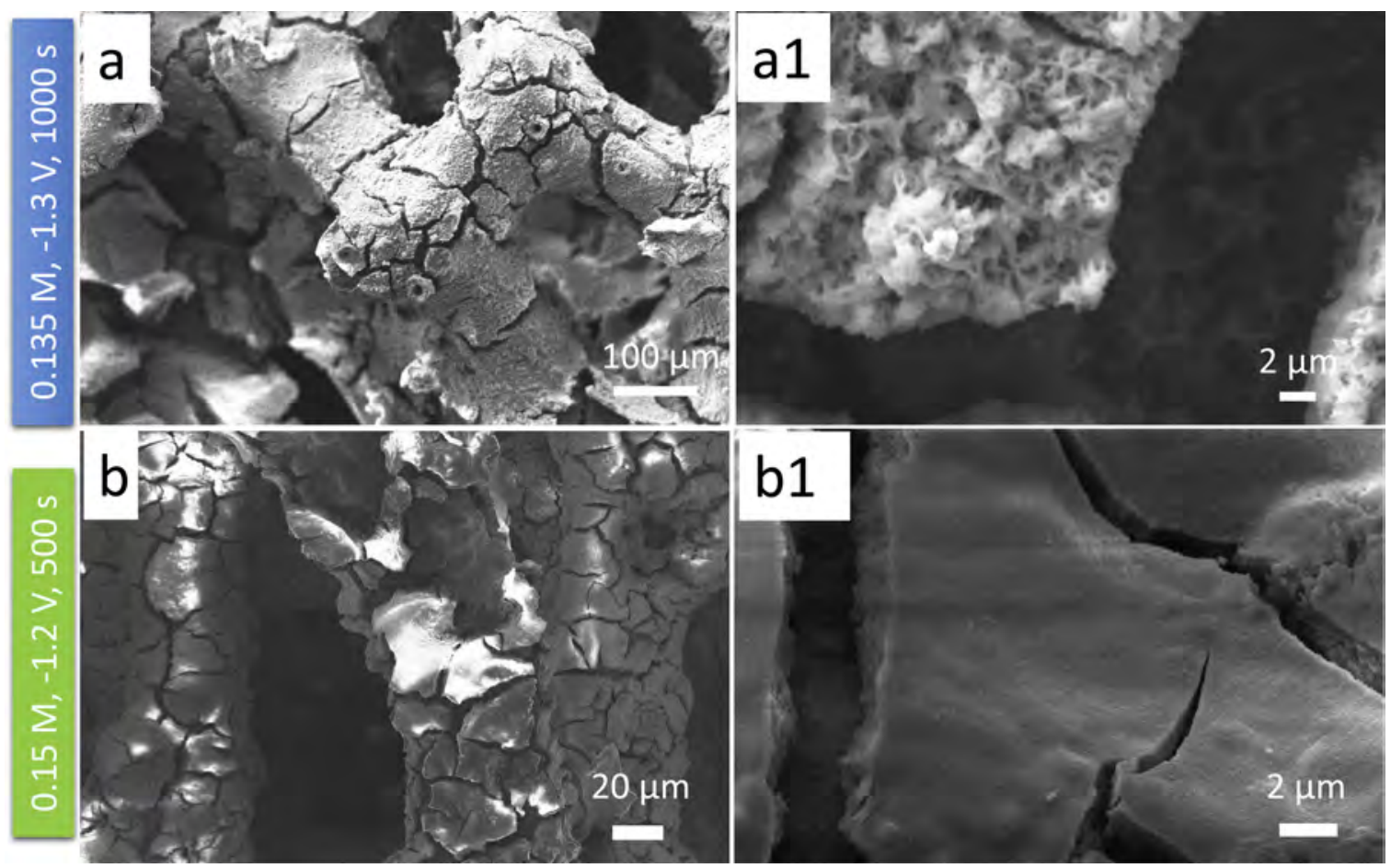

Fig. 7. SEM images of selected Pd-CeO ${ }_{2}$ calcined samples electrodeposited with electrolytes containing different $\mathrm{Pd}$ precursors: $\mathrm{Pd}\left(\mathrm{NH}_{3}\right)_{4}\left(\mathrm{NO}_{3}\right)_{2} 0.135 \mathrm{M},-1.3 \mathrm{~V}$, $1000 \mathrm{~s}$ (a, a1) and $\mathrm{PdCl}_{2} 0.15 \mathrm{M},-1.2 \mathrm{~V}, 500 \mathrm{~s}(\mathrm{~b}, \mathrm{~b} 1)$.

Tests at higher SLM better evidenced the differences among catalysts. For the catalyst prepared with the ammine precursor $(0.135 \mathrm{M}$, $-1.3 \mathrm{~V}, 1000 \mathrm{~s}$ ), at 4 SLM a plateau around $84 \%$ was attained at $295^{\circ} \mathrm{C}$. While at higher flow rates ( 5 and 6 SLM), the mass transfer limited regime was not achieved even above $400{ }^{\circ} \mathrm{C}$. Moreover, the conversion significantly decreased, around $10-12 \%$ every 1 SLM. In contrast, the samples prepared with chloride precursors exhibited much better catalytic performance when increasing the reactant flow rate. Although at 3 SLM the foam coated with the $0.15 \mathrm{M}$ solution at $-1.2 \mathrm{~V}$ showed slightly lower CO conversion than the one obtained with the $0.135 \mathrm{M}$
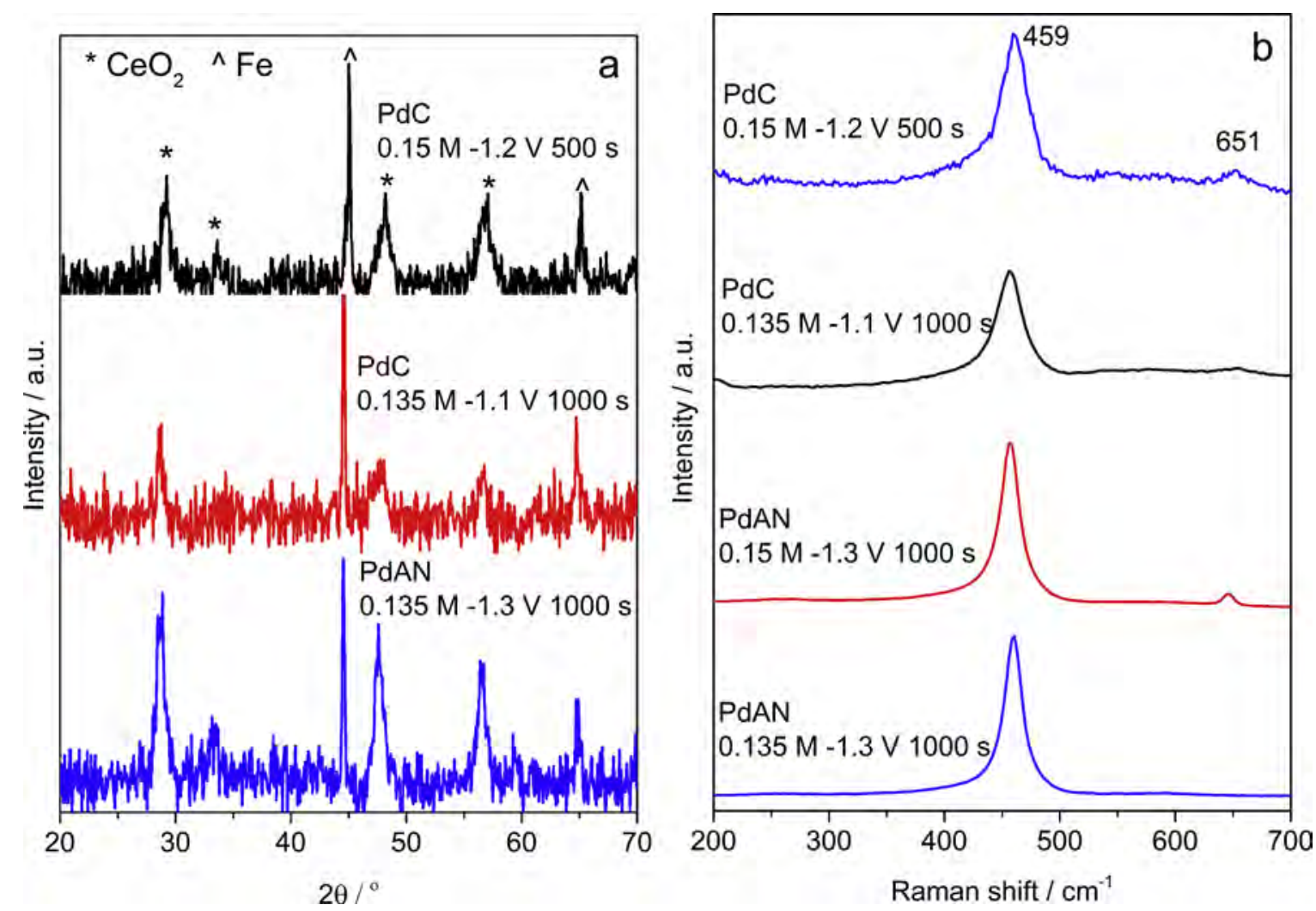

Fig. 8. XRD patterns (a) and Raman spectra (b) of calcined $\mathrm{Pd}-\mathrm{CeO}_{2}$ catalysts prepared with the ammine (PdAN) and chloride (PdC) precursors. 


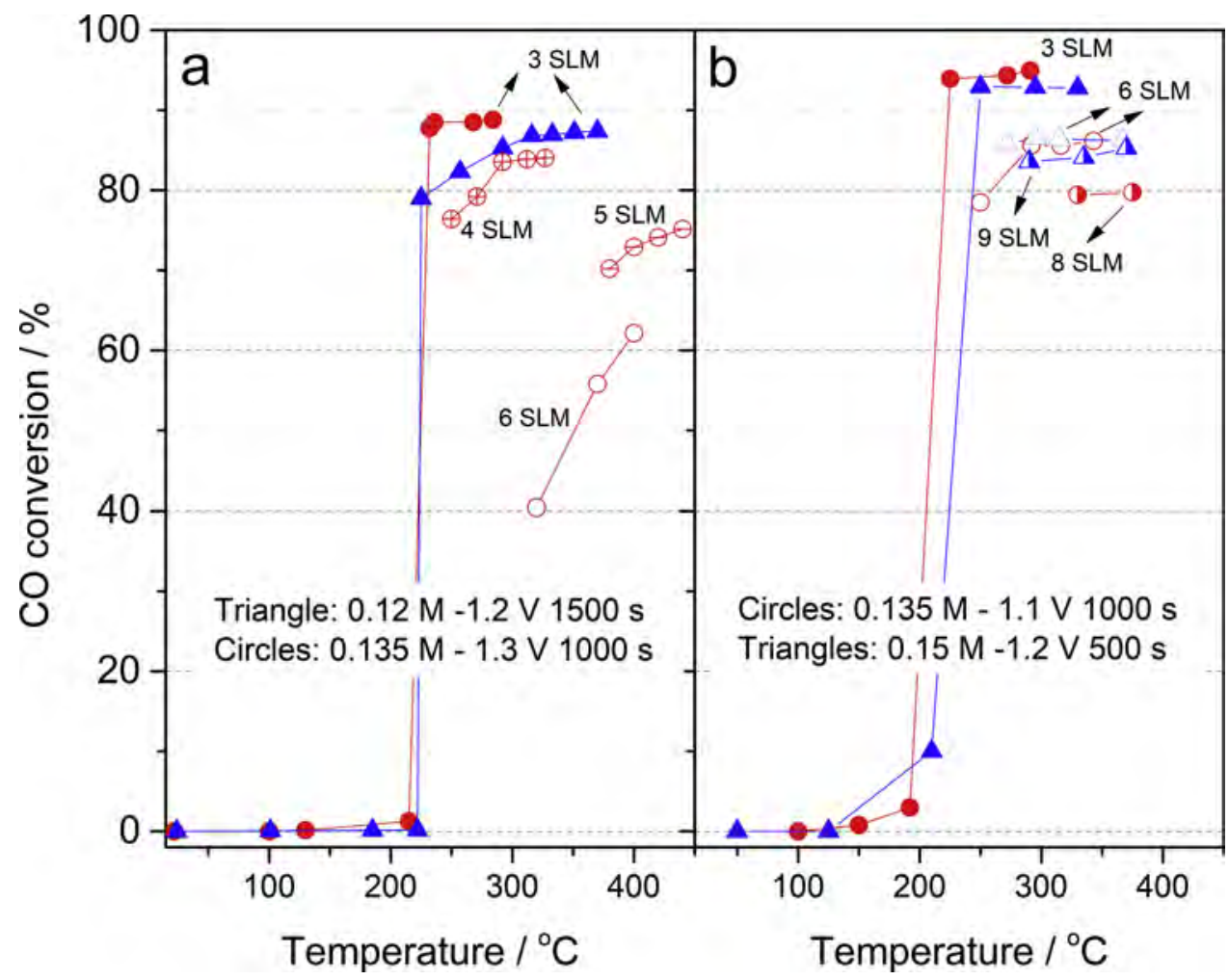

Fig. 9. CO ignition curves (3\% CO concentration) at different 3 SLM tests for foams coated with ammine (a) and chloride (b) containing electrolytes.

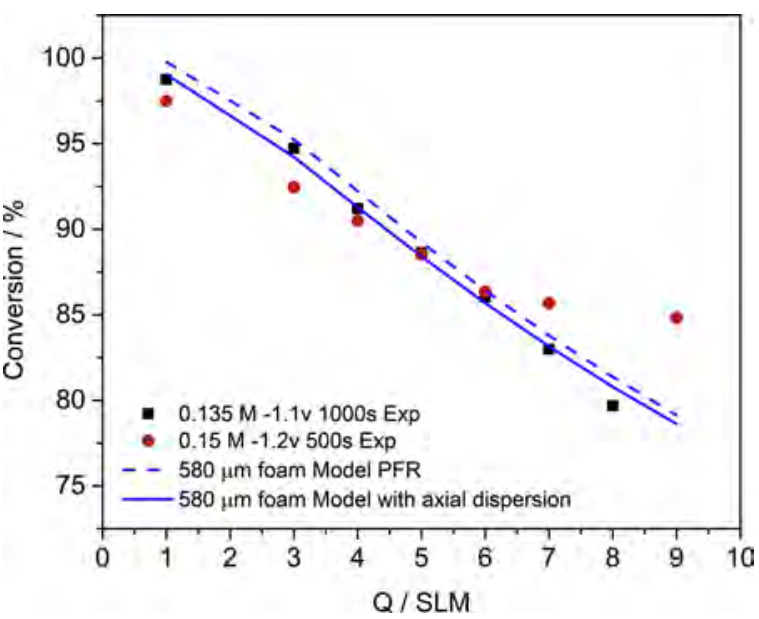

Fig. 10. Comparison of mass transfer performances of samples $0.15 \mathrm{M}-1.2 \mathrm{~V}$ $500 \mathrm{~s}$ (red circles), $0.135 \mathrm{M}-1.1 \mathrm{~V} 1000 \mathrm{~s}$ (black squares), prediction of mass transfer model with a surface utilization factor equal to 0.75 without axial dispersion (dashed line) and with axial dispersion (solid line) (For interpretation of the references to colour in this figure legend, the reader is referred to the web version of this article).

electrolyte at $-1.1 \mathrm{~V}$, at $6 \mathrm{SLM}$ their catalytic performances were comparable. However, at the highest flow rate tested, the former still exhibited an $84 \%$ CO conversion at 9 SLM, while the latter showed a lower CO conversion (80\%) even at a lower flow rate of 8 SLM.

The coatings were rather stable with time-on-stream; some more cracks and partial detachments were observed mainly in the compact layer of the catalysts prepared with chloride precursors than those with ammine ones as shown in Fig. S10, probably related to the platelet morphology of the latter that better withstand thermal and mechanical stresses. However, it should be noted that the PdC $0.15 \mathrm{M}-1.2 \mathrm{~V} 500 \mathrm{~s}$ sample showed high activity and stability after $48 \mathrm{~h}$ time-on-stream and different thermal cycles in our previous work [28].
The catalytic activity results pointed out the importance of the coating and Pd distribution in the activity of structured catalysts in the CO oxidation already observed by some of us [45]. The light-off temperature is mainly governed by chemical kinetics, i.e. the catalyst amount. In the mass-transfer controlled regime, the active catalyst surface accessible to the reactants and fluid-dynamic operating conditions are responsible of the reaction rate. An assessment of the mass transfer performances was performed comparing the experimental measurements against the conversion estimated adopting the mass transfer correlation for open cell foams developed by Bracconi et al. [46]. Such evaluation needs to accurately describe the geometrical properties of the coated foams. In this regard, the model of Ambrosetti et al. [47] was employed, adopting the same strategy described in [46] to account for the presence of the coating. In [28] a coating thickness equal to $5 \mu \mathrm{m}$ was measured with $\mu \mathrm{CT}$, similar values were detected for other samples by SEM pictures, hence that value was used as reference value to estimate foam morphology after the washcoat deposition. To understand the effect of axial dispersion, in Fig. 10, conversions calculated with a plug-flow reactor (PFR) model with and without dispersions (dashed and solid lines respectively) are presented. Reactor Peclet numbers in the range [20-200] were employed for the experimental tests, thus limiting the impact of axial dispersion on estimated conversions. The experimental curves present a deviation from the ideal mass transfer conversions, which might be due to partially coated surface, non-uniform Pd distribution and/or pore clogging. Overall an effective surface utilization factor equal to 0.75 was calculated, to fit the deviations in terms of volumetric mass transfer rates between the simulations and the experiments. A deviation for the $0.15 \mathrm{M}-1.2 \mathrm{~V}$ $500 \mathrm{~s}$ was observed without any physical explanation.

Thus the catalytic behaviours not only depended on the homogeneity and thickness of the coating but also on the distribution and number of Pd active sites. Both types of Pd precursors generated comparable homogeneity of the coating, however, the better control of Pd content and distribution in case of the chloride than with the ammine $\mathrm{Pd}^{2+}$ precursor, and probably the higher coating loading, especially using a high electrolyte concentration (i.e. $0.15 \mathrm{M}$ ) and applying a 
$-1.2 \mathrm{~V} v s$ SCE potential for short times (i.e. $500 \mathrm{~s}$ ) resulted in a superior catalytic performance even at very high GHSV values. However, the role of the type of $\mathrm{Pd}$ species in the activity, $\mathrm{Pd}^{\circ}$ and $\mathrm{Pd}^{2+}$, and their reducibility and sintering with time-on-stream could not be discarded to contribute to the activity $[28,44,48,49]$.

\section{Conclusions}

The basic $\mathrm{pH}$ reached in the electrode-electrolyte interface by application of a cathodic potential to a foam dipped in a Ce( $\left(\mathrm{NO}_{3}\right)_{3}$ electrolyte allowed to prepare cubic fluorite $\mathrm{CeO}_{2}$ coatings containing defects on small pore size metallic foams under a wide range of conditions and with a high reproducibility. The concentration of the $\mathrm{Ce}\left(\mathrm{NO}_{3}\right)_{3}$ precursor, potential applied and synthesis time controlled not only the thickness but also the morphology of the coatings, compact and platelet-like. Diluted baths generated a compact coating prone to crack formation during drying and calcination steps. Larger and interconnected platelets were obtained with concentrated solutions, which decreased the crack development, followed by the deposition of a compact layer laying on them. The calcination increased the crystallinity of $\mathrm{CeO}_{2}$, but some defects and the surface reduction peak in $\mathrm{H}_{2}$-TPR profile were still identified.

The electrochemistry and chemistry of $\mathrm{Pd}^{2+}$ should be considered in the one-step preparation of $\mathrm{Pd}-\mathrm{CeO}_{2}$ coatings. The type of $\mathrm{Pd}^{2+}$ precursor determined the Pd content and distribution as well as the morphology of $\mathrm{CeO}_{2}$ particles. The $\left[\mathrm{Pd}\left(\mathrm{NH}_{3}\right)_{4}\right]^{2+}$ complex, due to its intermediate degree of stability in basic media, increased the reduction potential delaying the formation of $\mathrm{Pd}^{\circ}$ but also the palladium incorporation into $\mathrm{CeO}_{2}$. A good coverage of the foam surface by mainly $\mathrm{CeO}_{2}$ platelets, very stable after calcination, was achieved in a wide range of deposition conditions. Nevertheless, a $-1.3 \mathrm{~V} v s$ SCE potential combined with a $0.135 \mathrm{M}$ electrolyte concentration and $1000 \mathrm{~s}$ deposition time were the best conditions individuated to increase the Pd loading limiting the $\mathrm{Pd}^{\circ}$ deposition. The palladium chloride complex, probably $\left[\mathrm{PdCl}_{3}\right]\left[\mathrm{H}_{2} \mathrm{O}\right]^{-}$, was more easily reduced, but either a further increase in the electrolyte concentration $(0.15 \mathrm{M})$ and a shorter time $(500 \mathrm{~s})$ or a less negative potential $(-1.1 \mathrm{~V}$ vs SCE), allowed a rather controlled deposition of dispersed $\mathrm{Pd}^{2+}$ species on the $\mathrm{CeO}_{2}$ coating made by both platelets and compact layers.

Better control of Pd content and distribution in case of chloride than with ammine precursor resulted in a superior catalytic performance in the $\mathrm{CO}$ oxidation, reaching the mass transfer controlled regime even at very high GHSV values.

\section{Acknowledgements}

P.H. Ho thanks to SINCHEM grant for $\mathrm{PhD}$ research fellowship. SINCHEM is a joint-doctorate programme selected under Erasmus Mundus Action 1 programme (FPA 2013-0037).

\section{Appendix A. Supplementary data}

Supplementary data associated with this article can be found, in the online version, at https://doi.org/10.1016/j.cattod.2019.02.005.

\section{References}

[1] T. Montini, M. Melchionna, M. Monai, P. Fornasiero, Chem. Rev. 116 (2016) 5987-6041.

[2] J.W. Kim, B.K. Choi, M.J. Jang, Metal Foam Stack and Manufacturing Method Therefor, Patent US 20170210090 A1, (2017).

[3] Q. Zhang, Y. Li, R. Chai, G. Zhao, Y. Liu, Y. Lu, Appl. Catal. B Environ. 187 (2016) 238-248.

[4] G. Landi, P.S. Barbato, A. Di Benedetto, L. Lisi, Appl. Catal. B Environ. 181 (2016)
727-737

[5] C. Italiano, R. Balzarotti, A. Vita, S. Latorrata, C. Fabiano, L. Pino, C. Cristiani, Catal. Today 273 (2016) 3-11.

[6] V. Palma, D. Pisano, M. Martino, Int. J. Hydrog. Energy 42 (2017) 23517-23525.

[7] M. González-Castaño, S. Ivanova, O.H. Laguna, T. L.M. Martínez, M.A. Centeno, J.A. Odriozola, Appl. Catal. B Environ. 200 (2017) 420-427.

[8] R.J. Gorte, AIChE J. 56 (2010) 1126-1135.

[9] E. Tronconi, G. Groppi, C.G. Visconti, Curr. Opin. Chem. Eng. 5 (2014) 55-67.

[10] A.J. Aldykiewicz Jr., A.J. Davenport, H.S. Isaocs, J. Electrochem. Soc. 143 (1996) 147-154.

[11] Y. Zhou, J.A. Switzer, J. Alloys Compd. 237 (1996) 1-5.

[12] P. Stefanov, G. Atanasova, D. Stoychev, Ts. Marinova, Surf. Coat. Technol. 180-181 (2004) 446-449.

[13] I. Zhitomirsky, A. Petric, Mater. Lett. 40 (1999) 263-268.

[14] B. Bouchaud, J. Balmain, G. Bonnet, F. Pedraza, Electrochim. Acta 88 (2013) 798-806.

[15] L. Arurault, B. Daffos, F.X. Sauvage, Mater. Res. Bull. 43 (2008) 796-805.

[16] I. Yamaguchi, M. Watanabe, T. Shinagawa, M. Chigane, M. Inaba, A. Tasaka, M. Izaki, ACS Appl. Mater. Interfaces 1 (2009) 1070-1075.

[17] L. Yang, X. Pang, G. Fox-Rabinovich, S. Veldhuis, I. Zhitomirsky, Surf. Coat. Technol. 206 (2011) 1-7.

[18] Y. Hamlaoui, F. Pedraza, L. Tifouti, Corros. Sci. 50 (2008) 2182-2188.

[19] Y. Hamlaoui, F. Pedraza, C. Remazeilles, S. Cohendoz, C. Rébéré, L. Tifouti, J. Creus, Mater. Chem. Phys. 113 (2009) 650-657.

[20] L. Arurault, P. Monsang, J. Salley, R.S. Bes, Thin Solid Films 446 (2004) 75-80.

[21] E. Verlato, S. Barison, S. Cimino, L. Lisi, G. Mancino, M. Musiani, F. Paolucci, Chem. Eng. J. 317 (2017) 551-560.

[22] B. Bouchaud, J. Balmain, G. Bonnet, F. Pedraza, Appl. Surf. Sci. 268 (2013) 218-224.

[23] Y.-N. Ou, G.-R. Li, J.-H. Liang, Z.-P. Feng, Y.-X. Tong, J. Phys. Chem. C 114 (2010) 13509-13514.

[24] J. Yang, S. Xu, W. Chen, J. Zang, J. Zhang, J. Electroanal. Chem. 670 (2012) 62-66.

[25] K. Kamada, N. Enomoto, J. Hojo, Electrochim. Acta 54 (2009) 6996-7000.

[26] V. Lair, L.S. Živković, O. Lupan, A. Ringuedé, Electrochim. Acta 56 (2011) $4638-4644$.

[27] Y. Kozu, S. Kawashima, F. Kitamura, J. Solid State Electrochem. 17 (2013) $761-765$

[28] P.H. Ho, M. Ambrosetti, G. Groppi, E. Tronconi, J. Jaroszewicz, F. Ospitali, E. Rodríguez-Castellón, G. Fornasari, A. Vaccari, P. Benito, Catal. Sci. Technol. 8 (2018) 4678-4689.

[29] C.R.K. Rao, D.C. Trivedi, Coord. Chem. Rev. 249 (2005) 613-631.

[30] J.A. Abys, Palladium electroplating, in: M. Schlesinger, M. Paunovic (Eds.), Modern Electroplating, fifth ed., Willey, 2011, pp. 327-368.

[31] F. Kettemann, M. Wuithschick, G. Caputo, R. Kraehnert, N. Pinna, K. Rademann, J. Polte, CrystEngComm 17 (2015) 1865-1870.

[32] K. Mech, P. Żabiński, R. Kowalik, K. Fitzner, Electrochim. Acta 104 (2013) $468-473$.

[33] K. Mech, P. Żabiński, R. Kowalik, K. Fitzner, J. Electroanal. Chem. 685 (2012) 15-20.

[34] P. Vanýsek, Electrochemical series, in: W.M. Heynes (Ed.), CRC Handbook of Chemistry and Physics, CRC Press, Boca Raton, 2016, pp. 78-84.

[35] P.H. Ho, W. de Nolf, F. Ospitali, A. Gondolini, G. Fornasari, E. Scavetta, D. Tonelli, A. Vaccari, P. Benito, Appl. Catal. A Gen. 560 (2018) 12-20.

[36] P.H. Ho, E. Scavetta, F. Ospitali, D. Tonelli, G. Fornasari, A. Vaccari, P. Benito, Appl. Clay Sci. 151 (2018) 109-117.

[37] F. Giordano, A. Trovarelli, C. de Leitenburg, M. Giona, J. Catal. 193 (2000) 273-282.

[38] E.M. Slavinskaya, R.V. Gulyaev, A.V. Zadesenets, O.A. Stonkus, V.I. Zaikovskii, Yu.V. Shubin, S.V. Korenev, A.I. Boronin, Appl. Catal. B Environ. 166-167 (2015) 91-103.

[39] X. Wang, D. Liu, J. Li, J. Zhen, F. Wang, H. Zhang, Chem. Sci. 6 (2015) 2877-2884.

[40] M. Hasan, W. Khunsin, C.K. Mavrokefalos, S.A. Maier, J.F. Rohan, J.S. Foord, ChemElectroChem 5 (2018) 619-629.

[41] I. Danaee, J. Electroanal. Chem. 662 (2011) 415-420.

[42] L.A. Kibler, M. Kleinert, R. Randler, D.M. Kolb, Surf. Sci. 443 (1999) 19-30.

[43] C.-B. Wang, H.-K. Lin, C.-M. Ho, J. Molec, Catal. A Chem. 180 (2002) 285-291.

[44] M. Kurnatowska, L. Kepinski, W. Mista, Appl. Catal. B Environ. 117-118 (2012) 135-147.

[45] L. Giani, C. Cristiani, G. Groppi, E. Tronconi, Appl. Catal. B Environ. 62 (2006) $121-131$.

[46] M. Bracconi, M. Ambrosetti, M. Maestri, G. Groppi, E. Tronconi, Chem. Eng. J. 352 (2018) 558-571.

[47] M. Ambrosetti, M. Bracconi, G. Groppi, E. Tronconi, Chem. Ing. Tech. 89 (2017) 915-925.

[48] A.I. Boronin, E.M. Slavinskaya, I.G. Danilova, R.V. Gulyaev, Yu.I. Amosov, P.A. Kuznetsov, I.A. Polukhina, S.V. Koscheev, V.I. Zaikovskii, A.S. Noskov, Catal. Today 144 (2009) 201-211.

[49] E. Sasmaz, C. Wang, M.J. Lance, J. Lauterbach, J. Mater. Chem. A 5 (2017) 12998-13008. 